\title{
EFFICACY OF SOME PLANT ACTIVE INGREDIENTS AS MOLLUSCICIDES AGAINST THE GLASSY CLOVER LAND SNAIL, MONACHA OBSTRUCTA
}

\author{
Mona A. Ali, Ghada E. Abd- Allah and Amal E. Marouf \\ Plant Protection Research Institute, Dokki, Giza, Egypt
}

Received: Jan. 14, 2017

Accepted: Jan. 31, 2017

\begin{abstract}
This study aimed to evaluate the bioactivity of some active ingredients of plant extracts, menthol, camphor and their combination, on the adults of clover land snail, Monacha obstructa (Montagu) by two methods of application, leaf dipping method and contact method (thin layer film). Also, sub-lethal concentration $\left(1 / 4 L C_{50}\right)$ of the combination using the contact method (thin layer film) was used to measure some biochemical parameters as alanine amino transaminase (ALT), aspartate amino transaminase (AST), alkaline phosphatase (ALP) and acid phosphatase $(A C P)$. The results revealed that, the combination of camphor and menthol was more effective than each ingredient alone, by the two application methods, with $L C_{50} 11757.11$ and 8907.73, respectively. However, the results of all biochemical parameters, (ALT, AST, ALP $\& A C P)$ for the tested samples were significantly different from control.
\end{abstract}

Key words: Monacha obstructa, camphor, menthol, biochemical effects.

\section{INTRODUCTION}

Land snails are serious pests attacking the vegetation including vegetables, horticultural plants and field crops in most area of Egypt. Monacha obstructa (Montagu) is the most common and serious pests in Egypt. It caused a substantial damage to different agricultural crops in various governorates. Many environmental problems such as the harmful effects against nontarget organisms including mammals, poultry and wildlife result from using synthetic compounds. Some attempts were carried out to evaluate alternative, effective natural pesticides to replace the conventional synthetic pesticides (Abdelgaleil, 2005; Khidr et al., 2006; El-Zemity and Radwan, 2001; Hussein et al. 1994, 1999, 2007a, b). Natural products are an excellent alternative to synthetic pesticides as a means to reduce negative impacts towards to human health and the environment (Opender et al., 2008). Transaminases enzymes are important in the biological processes in the land snails (Abd El-Ail, 2004).

The aim of this work was to determine the effect of some active ingredients and their combination on mortality of the land snail, $M$. obstructa and on the activities of vital enzymes. The enzymes selected for this study were, alanine amino transaminase (ALT), aspartate amino transaminase (AST), alkaline phosphatase (ALP) and acid phosphatase (ACP).

\section{MATERIALS AND METHODS Tested snails:}

Adult individuals of the glassy clover snail, Monacha obstructa were collected from untreated clover field at Dakahlia Governorate. The snails were transferred directly in muslin bags to the laboratory and were kept in glass boxes and fed on fresh lettuce leaves (El-Deeb et al. 2003) for two weeks for acclimatization. Healthy adult snails with the same shell diameter were selected for each treatment.

\section{Tested plant active ingredients:}

Camphor is crystalline material, $\left(\mathrm{C}_{10} \mathrm{H}_{16} \mathrm{O}\right)$ and bought from (El- Gomhoria company-Mansoura).

Menthol is crystalline material $\left(\mathrm{C}_{10} \mathrm{H}_{20} \mathrm{O}\right)$ and was bought from (El- Gomhoria company-Mansoura).

Mixture of the two materials made by mix camphor and menthol 1:1 proportion (Amal, 2014; Salvador et al., 2014; Ghada and Amal, 2015). 


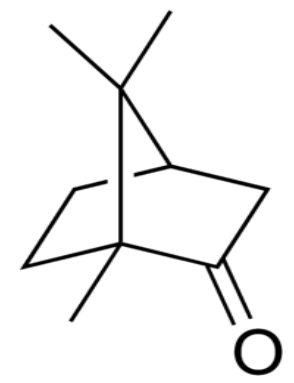

Camphor formula (Opender et al., 2008)

\section{Methods of application: 1-Leaf dipping method:}

This method was used to detect the toxicity action of the snail. The snails were fed on treated lettuce which dipped into the treatments for 20 seconds, then left for air dryness under laboratory conditions (Ghamry, 1994), 10 snails for each replicate were released to each leaf disc placed. Four concentrations and three replicated were used to estimate each concentrationmortality line. The same number of leaf discs per treatment was dipped into distilled water as an untreated check. The concentrations were 10000, 15000, 17500 and 20000 ppm for each ingredient. The mortality was recorded after one, three, five and seven days and the data were corrected relatively to control mortality (Abbott, 1925). LC $_{50}$ values were determined using probit analysis statistical method of Finney, 1971. Toxicity index of $\mathrm{LC}_{50}$ was computed according to the Equation of Sun, 1950 :

\section{Toxicity index of $\mathrm{LC}_{50}=$}

$\mathrm{LC}_{50}$ of the most effective compound

$\mathrm{LC}_{50}$ of the least effective compound

\section{2- Contact method:}

This method was used to detect the toxicity action on the body enzymes of the snail. The snails were treated with sublethal concentration $\left(1 / 4 \quad L_{50}\right)$ of each ingredient using thin layer film technique according to Ascher and Mirian (1981). Four concentrations and five replicates were used and 5 snails for each replicate. Two $\mathrm{ml}$ of each ingredient concentration were spread<smiles>CC(C)[C@H]1CC[C@@H](C)C[C@H]1O</smiles>

Menthol formula (Opender et al., 2008)

on the inner surface of a petri-dish by moving the dish gently in circles. Water was evaporated under room conditions in a few minutes leaving a thin layer film of the applied concentration. The snails were exposed to the concentrations of each ingredient and the results were taken after one, three, five and seven days. A parallel control test was conducted using water only.

\section{Biochemical studies: \\ Preparation of samples:}

Samples were prepared according to ElGohary (2011). After each days (one, three, five \& seven) shells of tested snails were removed by making a cut around the whorls in a continuous manner starting at the aperture opening using bone scissors and the broken fragments of the shell were carefully removed. Snails tissues were dissected out and all tissues of each treatment were homogenized in distilled water. The homogenates were centrifuged at $3000 \mathrm{rpm}$ for $15 \mathrm{~min}$. at $5^{\circ} \mathrm{C}$ in refrigerated centrifuge. The deposits were discarded and the supernatants were kept in a deep freezer till use to determine the activities of alanine amino transaminase (ALT), aspartate amino transaminase (AST), alkaline phosphatase (ALP) and acid phosphatase (ACP).

\section{Determination of ALT and AST:}

The activity of alanine amino transaminase (ALT) and aspartate amino transaminase (AST) was determined according to the method of Reitman and Frankel (1957) using commercial reagents. 
Determination of ALP and ACP:

Alkaline phosphatase (ALP) activity in haemolymph was estimated according to the method of DGKC (1972). Acid phosphatase (ACP) activity in haemolymph was measured following the method of Kind and King (1954).

\section{RESULTS AND DISCUSSION} 1- Toxicity Effect:

Efficiency of the active ingredients on Monacha obstructa by leaf dipping method:

The data in Table (1) indicated that, the mixture of camphor and menthol caused high mortality proportion on the adults of $M$. obstructa than menthol or camphor alone.

However, Table (2) and Fig. (1) Demonstrated that, the mixture of camphor and menthol was more effective than each one alone with $\mathrm{LC}_{50}: 11757.11 \mathrm{ppm}$ and the toxicity index was $100 \%$ for it. Camphor was following the mixture in the effectiveness on the snail with $\mathrm{LC}_{50}$ : 17555.65 . The slope values indicated that, the mixture of both ingredients had the lowest value was 2.08 followed by 2.51 and 2.87 for camphor and menthol, respectively. Hanan et al. (2012) proved that camphor extract has a significant effect on larval mortality of cotton leaf worm.

\section{Efficiency of the active ingredients on Monacha obstructa by contact method:}

Data shown through (Table 3) indicated that, the mixture of camphor and menthol caused high mortality proportion on the adults of $M$. obstructa than menthol or camphor alone. Ghada and Amal (2015) revealed that, the mixture of camphor and menthol had significant effect on $2^{\text {nd }}$ instar larvae of Spodoptera littoralis than everyone alone.

Table (1): Corrected mortality Monacha obstructa under laboratory conditions by leaf dipping method $25 \pm 2{ }^{\circ} \mathrm{C}$ and $75 \pm 5 \% \mathrm{RH}$.

\begin{tabular}{|c|c|c|c|c|c|c|}
\hline \multirow[b]{2}{*}{ Treatments } & \multirow{2}{*}{$\begin{array}{l}\text { Conc. } \\
\text { (ppm) }\end{array}$} & \multicolumn{4}{|c|}{ Mortality after treatments $\%$} & \multirow[b]{2}{*}{ Total Mortality \% } \\
\hline & & One day & $\begin{array}{l}\text { Three } \\
\text { days }\end{array}$ & $\begin{array}{l}\text { Five } \\
\text { days }\end{array}$ & $\begin{array}{c}\text { Seven } \\
\text { days }\end{array}$ & \\
\hline \multirow{4}{*}{ Camphor } & 10000 & - & 3.33 & 10 & 6.67 & 20.0 \\
\hline & 15000 & 10 & 10 & 6.67 & 6.67 & 33.33 \\
\hline & 17500 & 13.33 & 23.33 & 6.67 & 3.33 & 46.66 \\
\hline & 20000 & 16.67 & 30 & 13.33 & 10 & 70.0 \\
\hline \multirow{4}{*}{ Menthol } & 10000 & - & 3.33 & 6.67 & 10 & 20.0 \\
\hline & 15000 & 16.67 & 10 & - & 3.33 & 30.0 \\
\hline & 17500 & 3.33 & 16.67 & 16.67 & 10 & 46.0 \\
\hline & 20000 & 26.67 & 16.67 & 13.33 & 3.33 & 60.0 \\
\hline \multirow{4}{*}{$\begin{array}{l}\text { Mixture of } \\
\text { camphor }+ \\
\text { menthol }\end{array}$} & 10000 & 6.67 & 20 & 6.67 & 6.67 & 40.01 \\
\hline & 15000 & 33.33 & 6.67 & 3.33 & - & 43.33 \\
\hline & 17500 & 10 & 43.33 & 13.33 & - & 66.66 \\
\hline & 20000 & 26.67 & 30 & 16.67 & 6.67 & 80.01 \\
\hline
\end{tabular}


Ali, et al.,

Table (2): Efficiency of some plant active ingredients against Monacha obstructa by leaf dipping method.

\begin{tabular}{|c|c|c|c|c|c|c|c|c|}
\hline $\begin{array}{l}\text { Conc. } \\
\text { (ppm) }\end{array}$ & $\begin{array}{c}\text { corrected } \\
\text { mortality } \\
\%\end{array}$ & $\mathrm{LC}_{50}$ & $\mathrm{LC}_{90}$ & $\begin{array}{c}\text { Slope } \pm \\
\text { S.D. }\end{array}$ & $\begin{array}{c}\text { Toxicity } \\
\text { index } \\
\text { LC }_{50}\end{array}$ & $\begin{array}{l}\text { LC }_{90} / \\
\text { LC }_{50}\end{array}$ & $\mathrm{R}$ & P \\
\hline \multicolumn{9}{|c|}{ Camphor } \\
\hline 10000 & 20 & \multirow{4}{*}{17555.65} & \multirow{4}{*}{56911.66} & \multirow{4}{*}{$2.51 \pm 0.59$} & \multirow{4}{*}{77.36} & \multirow{4}{*}{3.24} & \multirow{4}{*}{0.894} & \multirow{4}{*}{0.142} \\
\hline 15000 & 33.33 & & & & & & & \\
\hline 17500 & 46.66 & & & & & & & \\
\hline 20000 & 70 & & & & & & & \\
\hline \multicolumn{9}{|c|}{ Menthol } \\
\hline 10000 & 20 & \multirow{4}{*}{18904.69} & \multirow{4}{*}{52846.34} & \multirow{4}{*}{$2.87 \pm 0.66$} & \multirow{4}{*}{71.54} & \multirow{4}{*}{4.14} & \multirow{4}{*}{0.97} & \multirow{4}{*}{0.609} \\
\hline 15000 & 30 & & & & & & & \\
\hline 17500 & 46 & & & & & & & \\
\hline 20000 & 60 & & & & & & & \\
\hline \multicolumn{9}{|c|}{ Mixture of camphor + menthol } \\
\hline 10000 & 40.01 & \multirow{4}{*}{11757.11} & \multirow{4}{*}{48652.35} & \multirow{4}{*}{$2.08 \pm 0.51$} & \multirow{4}{*}{100} & \multirow{4}{*}{4.14} & \multirow{4}{*}{0.876} & \multirow{4}{*}{0.140} \\
\hline 15000 & 43.33 & & & & & & & \\
\hline 17500 & 66.66 & & & & & & & \\
\hline 20000 & 80.01 & & & & & & & \\
\hline
\end{tabular}

R: Regression

P: Probability

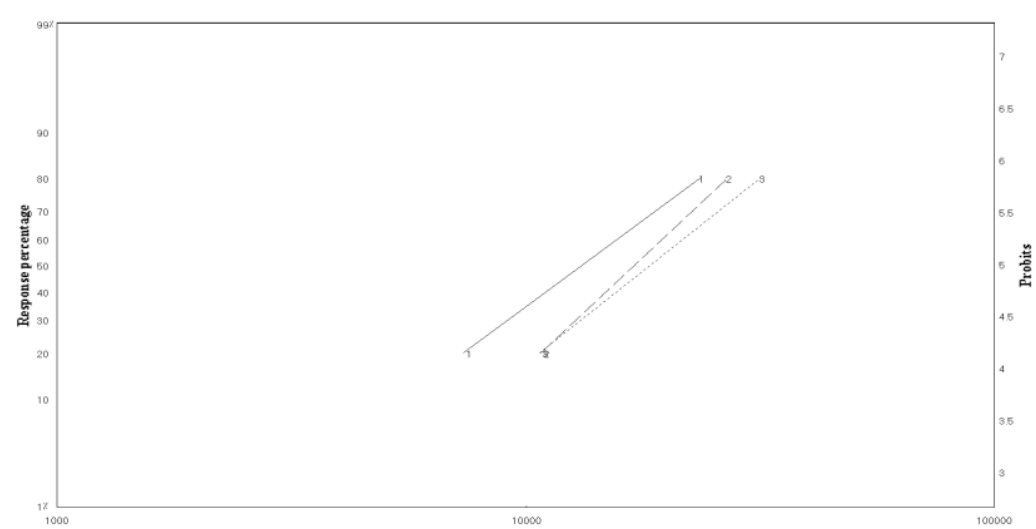

Fig. (1): LD-P lines for some plant active ingredients against the clover land snail, $M$. obstructa. 
Table (3): Corrected mortality by contact method of $M$. obstructa under laboratory conditions $25 \pm 2 \cdot \mathrm{C}$ and $75 \pm 5 \% \mathrm{RH}$.

\begin{tabular}{|c|c|c|c|c|c|c|}
\hline \multirow{2}{*}{ Treatments } & \multirow{2}{*}{$\begin{array}{l}\text { Conc. } \\
\text { (ppm) }\end{array}$} & \multicolumn{4}{|c|}{ Mortality after treatments $\%$} & \multirow{2}{*}{$\begin{array}{c}\text { Total } \\
\text { Mortality \% }\end{array}$} \\
\hline & & One day & Three days & $\begin{array}{l}\text { Five } \\
\text { days }\end{array}$ & Seven days & \\
\hline \multirow{4}{*}{ Camphor } & 10000 & 12 & 8 & 8 & - & 28 \\
\hline & 15000 & 16 & 16 & 8 & - & 40 \\
\hline & 17500 & 28 & 16 & 12 & - & 56 \\
\hline & 20000 & 40 & 16 & 4 & 8 & 68 \\
\hline \multirow{4}{*}{ Menthol } & 10000 & 16 & 8 & 8 & - & 32 \\
\hline & 15000 & 16 & 20 & 8 & 4 & 48 \\
\hline & 17500 & 32 & 20 & 12 & - & 64 \\
\hline & 20000 & 40 & 32 & 8 & - & 80 \\
\hline \multirow{4}{*}{$\begin{array}{l}\text { Mixture of } \\
\text { camphor }+ \\
\text { menthol }\end{array}$} & 10000 & 16 & 20 & 12 & - & 48 \\
\hline & 15000 & 28 & 12 & 20 & 4 & 64 \\
\hline & 17500 & 28 & 24 & 24 & - & 76 \\
\hline & 20000 & 48 & 40 & - & - & 88 \\
\hline
\end{tabular}

The mixture of active ingredients was more effective than each ingredient alone with $\mathrm{LC}_{50}$ : $8907.73 \mathrm{ppm}$ and with toxicity index $100 \%$, while LC $_{50}$ for camphor \& menthol was 15691.57\& 12958.78, respectively. These results showed through the Table (4) and Fig. (2). The obtained results were in agreement with Hussein et al. (2016) who proved that, the clover snail, M. obstructa was affected by the plant active ingredients. These results proved that, the effect of every ingredient increased when each one was added to each other. Salvador et al., 2014 was also proved that, mixtures of ethanolic plant extracts were more effective against food pathogen bacteria than each material alone.

\section{2- Biochemical Experiments:}

Effect of $1 / 4 \quad L C_{50}$ of the plant active ingredients on the snail biochemical activity :

\section{2-1- The effect of the mixture on AST and ALT enzymes:}

The results in Table (5) indicated that, there was highly significant difference in AST results in 1, 4 and 7 days and the control. The mixture of camphor and menthol increased ALT enzyme than control. This means that, diffusion of this enzyme from intracellular sites; this is may be due to the damage caused by the mixture on the sub- cellular level. These results were in agreement with Amer et al. (1994). While the results of AST enzyme were decreased than control. This decrease of the enzyme level may be due to the diffusion of this enzyme from the liver to the blood and through the kidney to outside with the urea or/ and due to the decrease in its synthetic due to liver tissue disorders. Also, these results were in agreement with Amer et al. (1994). 
$\underline{\text { Ali, et al., }}$

Table (4): Efficiency of some plant active ingredients against Monacha obstructa by contact method.

\begin{tabular}{|c|c|c|c|c|c|c|c|c|c|}
\hline $\begin{array}{c}\text { Conc. } \\
\text { (ppm) }\end{array}$ & $\begin{array}{c}\text { corrected } \\
\text { non } \\
\text { emergence } \\
\%\end{array}$
\end{tabular}

R: Regression P: Probability

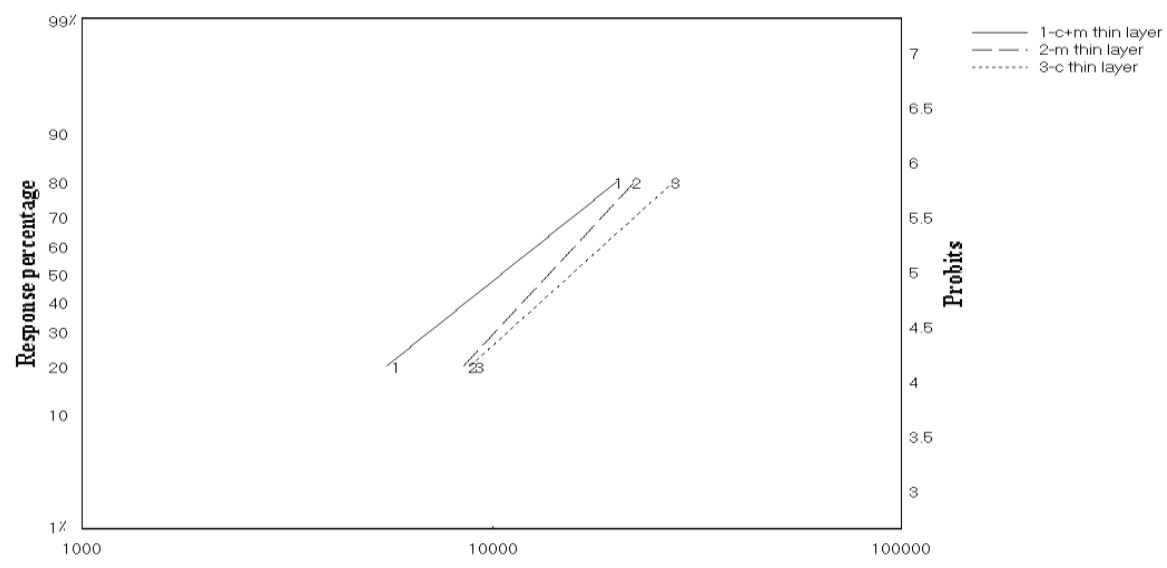

Fig. (2): LD-P lines for plant active ingredients against the clover land snail, $M$. obstructa. 


\section{2-2- The effect of the mixture on ALP and ACP:}

The results in Table (6) indicated that, there was highly significant difference in ALP results in 1,4 and 7 days and the control. There was high decrease between the obtained results and the control. Alkaline Phosphatase has critical roles on protein synthesis (Pilo et al., 1972) and shell formation (Timmermans, 1969). It plays an important role in spermatogenesis (Pavlikova and Repas, 1975). In the current study, exposure of $M$. obstructa snails to both sub lethal dose of the camphor and menthol mixture showed a marked inhibition in the activity of ALP enzyme. Reduction of ALP activity may be related to the cessation of protein synthesis due to the effect of the toxin on the general metabolism of the animal (Henderson and Triebskorn, 2002). However, the result of ACP enzyme activity was decreased than control. Acid phosphatase is a lysosomal enzyme and plays an important role in catabolism, pathological necrosis, autolysis and phagocytosis (Abu-Donia, 1978). In the present work, the mixture of the compounds cause the decreases of enzyme level may be due to disease or damage in the major organ of enzymes synthesis. Similar results have been obtained by Soha and Randa (2014).

Table (5): $1 / 4$ LC $_{50}$ effect of camphor+menthol mixture on aspartate transaminase (AST) and alanine transaminase (ALT) activities in M. obstructa at different periods of treatment

\begin{tabular}{|c|c|c|}
\hline \multirow[t]{2}{*}{ Days after treatment } & \multicolumn{2}{|c|}{$\begin{array}{c}\text { Parameters } \\
\text { mean of } 5 \text { snail } \pm \text { SE. }\end{array}$} \\
\hline & AST (U/ml) & ALT (U/ml) \\
\hline 1 & $3.52^{c} \pm 0.32$ & $8.154^{a} \pm 0.66$ \\
\hline 4 & $5.53^{b} \pm 0.52$ & $6.9^{b} \pm 0.32$ \\
\hline 7 & $0.99^{d} \pm 0.06$ & $2.26^{d} \pm 0.05$ \\
\hline Control & $12.5^{a} \pm 0.88$ & $4.81^{c} \pm 0.29$ \\
\hline LSD 0.05 & 1.62 & 1.19 \\
\hline
\end{tabular}

Values followed by the same letter (s) in each column are not significantly different

Table (6): $1 / 4 \mathrm{LC}_{50}$ effect of camphor+menthol mixture on alkaline phosphatase and acid phosphatase activities in M. obstructa at different periods of treatment

\begin{tabular}{|c|c|c|}
\hline \multirow{2}{*}{$\begin{array}{c}\text { Days after } \\
\text { treatment }\end{array}$} & \multicolumn{2}{|c|}{ Parameters (mean of 5 snail \pm SE) } \\
\cline { 2 - 3 } & $\begin{array}{c}\text { Alkaline phosphatase (ALP) } \\
\text { activity (U/L) }\end{array}$ & $\begin{array}{c}\text { Acid phosphatase (ACP) } \\
\text { activity (U/L) }\end{array}$ \\
\hline 1 & $132.93^{\mathrm{d}} \pm 2.06$ & $2.48^{\mathrm{b}} \pm 0.03$ \\
\hline 4 & $276.06^{\mathrm{b}} \pm 4.4$ & $2.38^{\mathrm{b}} \pm 0.06$ \\
\hline 7 & $165.45^{\mathrm{c}} \pm 2.92$ & $2.09^{\mathrm{b}} \pm 0.09$ \\
\hline Control & $362.84^{\mathrm{a}} \pm 2.48$ & $3.46^{\mathrm{a}} \pm 0.33$ \\
\hline LSD $\mathbf{0 . 0 5}$ & $\mathbf{9 . 3 2}$ & $\mathbf{0 . 5 2}$ \\
\hline
\end{tabular}

Values followed by the same letter (s) in each column are not significantly different 


\section{REFERENCES}

Abbott, W.S. (1925). A method of computing the effectiveness of an insecticide. J. Econ. Entomol., 18: 265-267.

Abd El- Ail, S. M. (2004). Toxicity and biochemical response of Eobania vermiculata land snail to niclosamide molluscicidae under laboratory and field conditions. J. Agric. Sci. Mansoura Univ., 29: 4751- 4756.

Abdelgaleil, S. A. M. (2005). Molluscicidal and insecticidal properties of sesquiterpene lactones and extracts of Magnolia grandiflora L. J. Pest Cont. Environ. Sci., 13 (1): 118.

Amal E. M. (2014). Influence of some plant oils on some biological aspects of the cotton leaf worm, Spodoptera littoralis (Biosd). J. Plant Prot. \& Path., 5 (4): 443448.

Amer, T. A., H.A. Ibrahim, M.E. Badawy and M.R. El- Sawi (1994). Curacron toxicity on some rat liver functions 1 - Nucleic metabolism and transaminase activity. J. Egy. Ger. Soc. Zol., 14; Comparative physiology. 123- 141.

Ascher, R.S. and F. Mirian (1981). The residual contact toxicity of Bay sir 8514 to Spodoptera littoralis larvae. Phytoparasitica, 9: 133- 137.

Abu-Donia, M. B. (1978). Increased acid phosphatase activity in hens following an oral dose of leptophos. Toxicol. Lett., 2 (4): 199-203.

Deutschen Gesellschaft für Klinische Chemie (DGKC) (1972). Empfehlungen der Deutschen Gesellschaft für Klinische Chemie. Recommendation of German Society of Clinical Chemistry (GSCC). J. Clin. Chem. Clin. Biochem., 10: 182-193.

El-Gohary, R.A. Laila and A.M. Genena (2011). Biochemical effect of three Molluscicide baits against the two land snails, Monacha obstructa and Eobania vermiculata (Gastropoda: Helicidae). Inter. J. Agric. Res., 6 (9): 682- 690.

El-Deeb, H.T., E.A. Ewels, M. A. Kandil, W. M. Gabr and Soha A. Mobarak (2003). Toxicity and biochemical studies of
Methomyl and Diazinon of different ages of the land gastropod species Monacha obstructa. J.Agric. Sci., Mansoura Univ., 28 (9): $7011-7023$.

El-Zemity, S. R. and M. A. Radwan (2001). Molluscicidal and antifeedant activity of some essential oils and their major chemical constituents against Theba pisana snails. Arab Univ. J. Agric. Sci. Ain Shams Univ. Cairo, 9(1):483 - 493.

Finney, D. J. (1971). Probit analysis. Cambridge Univ., London pp. 333.

Ghada, E. A. and E. M. Amal (2015). Control of cotton leaf worm, Spodoptera littoralis (Biosd) by some compounds of plant extracts. Egypt. J. Agric. Res., 93 (1A): 19.

Ghamry, E. M. (1994). Local cruciferous seeds having toxic effect against certain land snails under laboratory conditions. Egypt, J. App. Sci. 9 (3): 632-640.

Hanan, H. O., A.F. Badr El-Sabah and M. M. Abeer (2012). The potency of Chloropyrifos and Camphor extract on Spodoptera littoralis. Egypt. Acad. J. Biol. Sci.,5 (2):131-139.

Henderson, I. and R. Triebskorn (2002). Chemical control of terrestrial gastropods. In: Barker, G.M. (Ed.), Mollusks as crop pests. CABI Publishing, Wallingford, Oxon, UK. p.9.

Hussein, H. I., A. Kamel, M. Abou-Zeid, A. H. El-Sebae and M. Saleh (1994). Uscharin, the most potent molluscicidal compound tested against land snails. J. Chem. Ecol.,20:135-140.

Hussein, H. I., D. Al-Rajhy, F. El-Shahawi and S. Hashem (1999). Molluscicidal activity of Pergularia tomentosa (L), methomyl and methiocarb against land snails. Int. J. Pest. Manag. 45: 211-213.

Hussein, H. I., Y. Abo Bakr and E. H. Eshra (2007a). Molluscicidal activity and biochemical effects of two phytoglycosides against land snails. J. Adv. Agric. Res., 12(4): Accepted.

Hussein, H. I., E. H. Eshra and Y. Abo Bakr (2007b). Molluscicidal activity and Biochemical effects of certain 
monoterpenoids against land snails. J. Adv. Agric. Res., 12(4): Accepted.

Hussein, H. I., E. H. Eshra and Y. Abo Bakr (2016). Molluscicidal activity and biochemical effects of certain monoterpenoids against land snails. J. adv. Agric. Res., 12 (4): 679- 693.

Khidr, F. K., W. M. Gabr, A. S. Yousif and S. S. Hussein (2006). Biochemical effects of two natural pesticides on the brown garden snail Eobania vermiculata Muller. Egypt. J. Agric. Res., 84(3): 713-719.

Kind, P. R. N. and E. J. King (1954). Estimation of plasma phosphatase by determination of hydrolysed phenol with amino antipyrine. J. Clin. Path., 7: 322326.

Opender, K., W. Suresh and G. S. Dhaliwal (2008). Essential oils as green pesticides: potential and constraints. Biopestic. Int. 4(1): 63-84.

Pavlikova, D. and S. Repas (1975). Comparative histochemical studies of changes in spermatogenesis and intertubular tissue at male sterility. Biol. Bratisl., 30: 889-895.

Pilo, B., M. B. Asnani and R. V. Shah (1972). Studies on wound healing and repair in pigeon. III. Histochemical studies on acid and alkaline phosphatase activity during the process. J. Anim. Morphol. Physiol., 19: 205-212.

Reitman, S. and S. Frankel (1957). A colorimetric method for the determination of serum glutamic oxaloacetic and glutamic pyruvic transaminase. Am. J. Clin. Path., 28: 56-63.

Salvador, E. V., A. E. Mayra, M. Diana, N. A. Cristobal and R. H. Raul (2014). Synergistic effects of ethanolic plant extract mixtures against food- borne pathogen bacteria. Afric. J. Biotecn., 13 (5): 699- 704.

Soha, M. K. and A. K. Randa (2014). Efficiency of different compounds against the principle Calcium precipitation parameters of terrestrial snails. Egypt. Acad. J. Biol. Sci., 6(2) 1 -10.

Sun,Y.P. (1950). Toxicity index an improved method of comparing the relative toxicity of insecticides. J. Econ. Entomol., 43 : 45-53.

Timmermans, L. P. M. (1969). Studies on shell formation in mollusks. Neth. J. Zool., 19: 417-523. 
كفاعة بعض المواد الفعالة النباتية كمبيدات للرخويات ضد قوقع البرسيم الزجاجى

$$
\begin{aligned}
& \text { منى عبد الحميد على ، غادة السيا عبد الله ، أمل السيد معروف } \\
& \text { معهد بحوث وقاية النبانات - الدقى - الجيزة - مصر }
\end{aligned}
$$

\section{الملخص العربى}

استهدفت الدراسة معرفة مدى تأثثر المواد الفعالة لبعض المستخلصات النباتية وخليط هذه المواد على قوقع

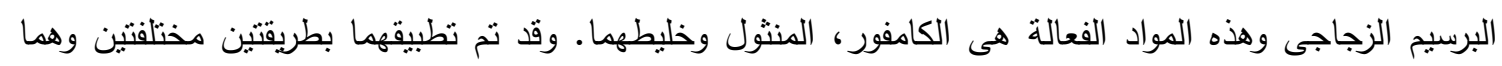

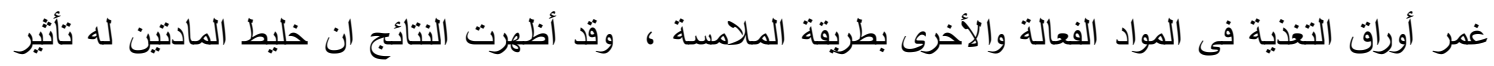

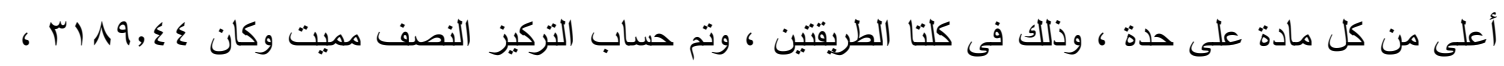

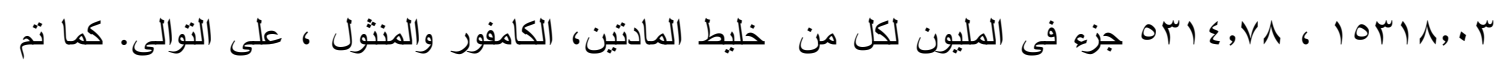
عمل تحليل لأربع أنواع من الانزيمات وذلك بتطبيق ربع التركيز نصف المميث لخليط المادتين لأنها الأكثر تأثثرا وقد أظهرت النتائج أن هناك تأثثرا سلبيا على انزيمات القوقع مقارنة بالكنترول. 